\title{
ATOS PERFORMATIVOS E MOVIMENTOS DO ACASO*
}

\author{
Samuel Edmundo Lopez Bello \\ Luís Fabiano de Oliveira
}

\begin{abstract}
Resumo
O texto realiza uma exposição de entendimentos sobre atos performativos a partir dos atos de fala de John L. Austin e dos atos do corpo de Judith Butler e possíveis aproximações com os conceitos de encenação, performance e de realização cênica desenvolvidos nos escritos de Max Herrmann. Apropriando-se das ideias de estética do performativo (Erika Fischer-Lichte) e de jogos de linguagem (Ludwig Wittgenstein), o texto volta-se para a incidência e importância do acaso nas realizações cênicas contemporâneas.
\end{abstract}

Palavras-chave: Acaso. Atos de fala. Atos do corpo. Realização cênica. Performativo. Jogos de linguagem.

A partir de agora, o teatro deixará de ser essa coisa fechada, aprisionada no espaço do palco, para converter-se num verdadeiro ato, submetido a todas as solicitações e distorções ditadas pelas circunstâncias, e na qual o acaso volta a ter importância. Com relação à vida, o Teatro Jarry tentará traduzir tudo o que a vida dissimula, esquece ou é incapaz de expressar.

Robert Aron, Antonin Artaud e Roger Vitrac; Manifesto do Teatro Jarry, Paris, 1928 (GLUSBERG, 2013, p. 22).

\section{Primeiro movimento. Wittgenstein e os jogos de linguagem. Bola para o alto.}

A linguagem, segundo Wittgenstein ${ }^{1}$, funciona em seus usos, em suas funções práticas (entendidas aqui como pragmáticas, isto é, naquilo que os falantes fazem com a língua, na atividade com que os indivíduos, inseridos em contextos sociais regulados e interagindo entre si de modo coordenado, produzem e interpretam significados). Estas funções apresentam-se em formas múltiplas e variadas, constituindo-se, por sua vez, em múltiplas linguagens (ou jogos de linguagem). Wittgenstein realiza analogias entre os jogos de linguagem e a utilização de ferramentas por operários.

Podemos imaginar também que todo o processo de uso de palavras em linguagem seja um dos jogos por meio dos quais as crianças aprendem sua língua materna. Quero chamar esses jogos de "jogos de linguagem", e falar de uma linguagem primitiva às vezes como de um jogo de linguagem.

\footnotetext{
* DOI - 10.29388/978-65-86678-51-2-0-f.317-336

${ }^{1}$ Ludwig Joseph Johann Wittgenstein (1889-1951) foi um filósofo austríaco, naturalizado britânico. Foi um dos principais autores da virada linguística na filosofia do século XX. Suas principais contribuições foram feitas nos campos da lógica, filosofia da linguagem, filosofia da matemática e filosofia da mente. Mais recentemente, percebe-se a produção de pesquisas em que alguns de seus conceitos, tais como "jogos de linguagem", "regras" e "formas de vida", são utilizados para pensar as artes da cena.
} 
E poder-se-ia chamar também de jogos de linguagem os processos de denominação das pedras e de repetição da palavra pronunciada. Pense em certo uso que se faz das palavras em brincadeiras de roda.

Chamarei de "jogo de linguagem" também a totalidade formada pela linguagem e pelas atividades com as quais ela vem entrelaçada. (WITTGENSTEIN, 2014, p. 1819).

O aforismo contido no parágrafo 18 das "Investigações Filosóficas" pode nos ser útil para a elaboração dos próximos movimentos.

Será que aqui a analogia da linguagem com o jogo não nos será esclarecedora? Podemos muito bem imaginar que pessoas se divertem num campo jogando bola e de tal modo que comecem diferentes jogos existentes, não joguem muitos deles até o fim, atirem a bola entrementes para o alto ao acaso, persigam-se mutuamente por brincadeira, atirando a bola etc. Então alguém diz: durante todo o tempo aquelas pessoas jogaram um jogo e se comportaram, a cada jogada, segundo determinadas regras. E não se dá também o caso em que jogamos e - "make up the rules as we go along"? E também o caso em que as modificamos - as we go along (WITTGENSTEIN, 2000, p. 58, grifos nossos).

O momento em que as regras são pactuadas dentro do jogo é da ordem variável; elas podem se constituir "à medida que avançamos" no jogo. O que aparenta ser imprescindível para a sua realização é o estabelecimento de regras conhecidas e existentes, e que estas não necessitem possuir objetivos a priori e estejam sujeitas ao acaso. $\mathrm{O}$ conhecimento compartilhado das regras do jogo é fundamental para os jogadores realizarem suas ações, sejam elas quais forem; sua materialidade e objetividade também se coloca como indispensável para a instauração de relações. Veja, por exemplo, o professor e alunos em uma atividade de ensino, tal qual os jogares do aforismo acima, divertem-se em uma sala jogando inicialmente a partir de aulas conhecidas e existentes previamente para, a seguir, criar conjuntamente seu conjunto de regras, certamente variáveis, algumas com menor ou maior duração temporal, mas que possibilitarão, por exemplo, a conclusão de um semestre. Os objetivos das regras não precisam se apresentar inicialmente de forma definida - a data de entrega dos trabalhos, se eles serão escritos ou apresentados oralmente, a duração do intervalo, o horário de início da aula, etc, mas sua existência se dá de forma complementar e constitutiva ao jogo. O conjunto de regras que possibilita a realização do jogo/aula é o que coloca em movimento as ações dos jogadores e abre espaço para a incidência do imprevisível, incerto, indeterminado - o acaso.

\section{Segundo movimento. Conceituando o acaso.}

Acaso como disruptivo, possibilidade criadora, como oposição ao que é necessário ou que ocorre sempre da mesma maneira. Para os estoicos ${ }^{2}$, onde a lógica do cosmo é absoluta, todos os acontecimentos são necessários. Partindo-se do pressuposto de que tudo está em mudança, o acaso seria inevitável. Para Bergson ${ }^{3}$, “[...] a vida é a causa do

\footnotetext{
2 O estoicismo é uma escola de filosofia helenística fundada na Grécia, em Atenas, por Zenão de Cítio no início do século III a.C., que, entre outras ideias, defendia que o universo é governado por uma razão universal natural.

${ }^{3}$ Henri Bergson (1859-1941) foi um filósofo e diplomata francês, tendo sua obra apropriada por diversos campos de pesquisa, como o cinema, a literatura, a neuropsicologia, a bioética, entre outros.
} 
movimento do mundo, e é por causa disso que ele define a existência como 'pura zona de indeterminação"' (SCHÖPKE, 2010, p. 14). Abbagnano assinala três conceitos de acaso com intersecções na história da filosofia:

[...] o conceito subjetivista, que atribui a imprevisibilidade e a indeterminação do evento casual à ignorância ou à confusão do homem; o conceito objetivista, que atribui o evento casual à mistura e à intersecção das causas; a interpretação moderna, segundo a qual o acaso é a insuficiência de probabilidades na previsão. Este último conceito é o mais geral e o menos metafísico (ABBAGNANO, 2012, p. 11).

Aproximando-nos do modo terapêutico de Wittgenstein praticar a filosofia onde, "[...] ainda que a Filosofia quase nada possa fazer, pode ainda fazer alguma coisa [...] levarse e levar ao divã todos os discursos que façam maus usos da linguagem e submetê-los a diferentes terapias [...] por maus usos da linguagem deve-se entender usos metafísicos da linguagem" (MIGUEL, 2016, p. 370, grifos do autor), cabe-nos desenvolver um pouco mais o último conceito de Abbagnano que interpreta o acaso como insuficiência de probabilidades na previsão.

Uma possibilidade de acesso à leitura moderna do conceito de acaso pode vir via $\mathrm{Hume}^{4}$, que realiza um processo de refutação às noções de causa e acaso. Segundo o filósofo, o entendimento de que as ações são guiadas por uma causa absoluta e necessária é irreal; por outro lado, o desconhecimento em relação ao que ele denomina como "causa real" de um acontecimento arrasta o acaso a ser lido como um evento de efeitos místicos, de crença ou de opinião. A verdadeira natureza do acaso, para Hume, é a de igualar inteiramente todos os eventos individuais que compreende (ABBAGNANO, 2012). Ele exemplifica com um jogo de dados, onde o jogador busca mentalmente prever qual o número que sairá vencedor, quando o aparecimento de cada lado é igualmente provável. Numa espécie de continuidade à ideia de Hume, Peirce ${ }^{5}$ enfatiza que "[...] o conceito de que o acaso consiste na equivalência de probabilidades que não dão acesso a uma previsão irrefutável em um sentido ou outro implica na eliminação do "necessitarismo", isto é, da doutrina segundo a qual tudo no mundo acontece por necessidade" (ABBAGNANO, 2012, p. 13).

\section{Terceiro movimento. $O$ acaso e tentativas de sua exclusão no teatro clássico e incorporação nas práticas artísticas contemporâneas. A intervenção do espectador.}

Podemos perceber as aparições dos conceitos de acaso de maneiras distintas quando caracterizamos o teatro clássico (ou dramático ${ }^{6}$ ) em relação ao teatro contemporâneo (que, em uma de suas vertentes, é pós-dramático).

\footnotetext{
${ }^{4}$ David Hume (1711-1776) foi um filósofo, historiador e ensaísta britânico nascido na Escócia que se tornou célebre por seu empirismo radical e ceticismo metafísico.

${ }^{5}$ Charles Sanders Peirce (1839-1914) foi um filósofo, pedagogista, cientista, linguista e matemático americano. Seus trabalhos apresentaram importantes contribuições à lógica, matemática, filosofia e, especialmente, à semiótica.

${ }^{6}$ Utilizaremos o conceito de dramático, ao longo do texto, no sentido de ação, como utilizado no teatro. Judith Butler também adotará esta significação quando se referir a dramático, conforme veremos mais adiante.
} 
O teatro clássico coloca em cena a narrativa de um conflito através do jogo de personagens; ele é representacional e necessariamente vinculado a um texto dramático que o antecede enquanto encenação. $\mathrm{O}$ acaso, entendido como da ordem do imprevisível, incerto, indeterminado, deve ser absolutamente excluído da representação dramática, visto como uma ameaça ao êxito da encenação e do jogo dos atores. As ações devem ser meticulosamente pensadas, criadas, ensaiadas e, ato contínuo, noite após noite, reproduzidas da mesma forma, com a devida intensidade, carga emocional e intencionalidade. O refletor que deixa de funcionar no meio da cena, o ator que esquece sua fala ou marcação (localização espacial na cena) ou o espectador que sofre um ataque do coração na primeira fila devem ser ignorados ou motivos de interrupção e cancelamento da apresentação. O evento teatral clássico possui um ritmo, convenções, partituras, que possuem regras estáveis e pré-determinadas ao acontecimento. As posições são claras e absolutamente distinguíveis: o dramaturgo escreve a obra literária, que contará com a figura de um diretor de cena (a partir do final do século dezenove) responsável pela concepção da encenação, os atores darão vida aos personagens a partir das indicações do dramaturgo e das orientações do diretor, cabendo aos espectadores o ato de fruir, assistir ao espetáculo e realizar mentalmente sua organização.

O teatro contemporâneo recebe várias denominações, dependendo de quais aspectos serão mais valorizados em relação a outros. Ele pode ser pós-dramático (priorizando-se a reescritura do conceito de dramaturgia); pós-moderno (análise centrada na figura do crítico/teórico, com tons de ironia); performático (a partir do privilégio do jogo dos atores); performativo (valorizando as relações que acontecem entre atores e espectadores); rapsódico (mistura de gêneros narrativos), etc. A narrativa prescinde de um conflito como unidade de ação, os atores deixam de interpretar personagens para assumir diversos papéis, entre eles, os seus próprios nomes (em algumas peças os atores informam seus $\mathrm{CPF}^{\prime} \mathrm{s}$ ao público). Em contraponto à ideia de representação é elaborado o conceito de presentificação; ao texto dramático surge o texto espetacular, que pode ser escrito e reescrito durante a própria encenação. $\mathrm{O}$ acaso é integrado como elemento de composição durante toda a construção da escritura cênica, atravessando a dramaturgia, a encenação e a atuação, que não mais estão submetidas a qualquer hierarquização ou cronologia, surgindo o que passaria a ser denominado como processo colaborativo. O espectador é chamado a atuar sobre o acontecimento teatral, tanto através de uma intervenção física quanto no papel de produtor de ressignificações ao que assiste.

Apesar de todas as evidentes distinções entre dois modelos teóricos, a prática da cena ensina que não há modelo totalmente fechado, imune a contaminações que conspurcarão sua identidade. Espetáculos onde há predominância de características clássicas ou dramáticas também apresentam elementos do chamado teatro contemporâneo e vice-versa. O que nos parece importante, numa abordagem analítica, é que dois aspectos são imprescindíveis nas diferentes possibilidades de teatralidades: o meticuloso processo de criação e ensaios e a construção do que consideramos jogos de linguagem entre artistas e espectadores (por mais que estas duas categorias possam trocar de papéis ocasionalmente). Se há uma intencionalidade de controle do acaso num teatro dramático e um desejado flerte com a imprevisibilidade no teatro contemporâneo, ambos acabam, de certas maneiras, por utilizá-lo e produzir novas significações. 
Ao final dos anos setenta, em Porto Alegre, integrantes do recém fundado Ói Nóis Aqui Traveiz (também conhecidos como atuadores da Terreira da Tribo ${ }^{\top}$ ) decidem intervir na cena de alguns espetáculos da capital gaúcha. Na condição de espectadores, em algum momento da apresentação dos espetáculos, eles se levantavam de seus lugares e começavam a interagir com os atores da peça, fazendo-se passar por personagens que criavam de acordo com a ação desenvolvida no palco. Ao caminhar em direção ao palco, um dos integrantes do Ói Nóis fez com que a diretora de uma peça resolvesse rapidamente fechar as cortinas e interromper sua apresentação; em outro caso, um ator, no palco, começou a discutir e proferir ameaças contra um dos "desordeiros" que, em pé e falando alto na plateia, insistia em atrapalhar o espetáculo ${ }^{8}$. O conhecido dramaturgo Plínio Marcos ${ }^{9}$, quando de um debate posterior à apresentação de uma de suas peças no Teatro de Arena ${ }^{10}$, afirmou ser revoltante a postura dos jovens integrantes do novo grupo teatral, o que levou a um princípio de pancadaria no local, visto que dois integrantes da Terreira da Tribo estavam no teatro ${ }^{11}$...Poderíamos afirmar que, no primeiro caso de intervenção, tivemos uma manifestação casual para os atores do espetáculo, que não imaginavam ser possível um espectador interagir com eles? Ao tornar-se repetitiva esta prática, levando inclusive projeções de quando e onde ela ocorreria novamente, esta ação performática deixou de ser imprevisível?

\section{Quarto movimento. Austin. Os performativos nos atos de fala.}

O conceito de "performativo" foi criado por John L. Austin ${ }^{12}$, que o introduziu na terminologia da filosofia da linguagem no ciclo de conferências How to do things with words? $?^{13}$ apresentado em 1955 na Universidade de Harvard. O nascimento deste conceito teve lugar aproximadamente na mesma época em que foram registradas as primeiras experiências performativas nas $\operatorname{artes}^{14}$. Sua intenção era a de diferenciar sentenças proferidas que não possuíam o caráter de descrever o ato que estaria sendo praticado, declarar o que está sendo praticado ou que possam ter conotação de verdadeiro ou falso: estas sentenças, ao serem proferidas, são realizadas ao mesmo tempo. Segundo Austin, “[...] que nome daríamos a

\footnotetext{
${ }^{7}$ A Tribo de Atuadores Ói Nóis Aqui Traveis é um grupo teatral surgido em Porto Alegre em 31 de março de 1978, que prioriza a pesquisa teatral. $\mathrm{O}$ grupo foi criado com o intuito de subverter a estrutura das salas de espetáculos e com o ímpeto de levar o teatro para a rua, abrindo novas perspectivas na tradicional performance cênica do sul do país.

${ }^{8} \mathrm{O}$ relato destes episódios nos foi narrado por um dos fundadores do grupo, Paulo Flores, na sede da Terreira da Tribo, em 13/10/2009. O primeiro espetáculo foi Frankie, Frankie, Frankenstein, apresentado no teatro Alziro Azevedo do Departamento de Arte Dramática da Universidade Federal do Rio Grande do Sul (DAD/UFRGS). O segundo ocorreu no Teatro Municipal Renascença, mas Paulo Flores não conseguiu recordar o nome da peça.

${ }_{9}^{9}$ Plínio Marcos (1935-1999) foi um escritor brasileiro, autor de inúmeras peças de teatro, escritas principalmente na época do regime militar (1964-1985).

${ }_{10}$ O Teatro de Arena de Porto Alegre, fundado em 1967 por um grupo de atores independentes, notabilizou-se, na época do regime militar, como importante espaço para apresentação de peças censuradas pelo Estado, o que acarretou o fechamento do local em algumas oportunidades.

${ }^{11}$ Entrevista realizada em 26/10/2009 com o ator e professor do DAD/UFRGS, João Pedro de Alcântara Gil, que estava no Teatro de Arena na ocasião. Ele não lembra o nome do espetáculo, sendo que o debate e a posterior confusão ficaram gravadas de forma mais permanente.

12 John Langshaw Austin (1911-1960) foi um filósofo da linguagem britânico, notabilizado por sua teoria dos atos de fala, voltado à investigação do problema do sentido em filosofia.

${ }^{13}$ Tradução literal: como fazer coisas com palavras? Em português, o ciclo de conferências foi publicado como Quando dizer é fazer - palavras e ação.

${ }_{14}$ Consideram-se hoje que experimentações do compositor John Cage, do coreógrafo Merce Cunningham, do videomaker Name June Park e do escultor Allan Kaprow teriam inaugurado o que se passou a chamar posteriormente de performance art (PAVIS, 2008:284).
} 
uma sentença ou proferimento deste tipo? Proponho denominá-la sentença performativa ou proferimento performativo, ou, de forma abreviada, um performativo" (AUSTIN, 1990, p. 25). Ele considera que estes performativos poderiam ser de diferentes tipos, como contratuais ou declaratórios, mas especialmente operativos, no sentido de que servem para efetuar uma transação naquilo que constitui sua principal finalidade, não tendo o mero caráter de relatar as circunstâncias em que deveria se efetuar a transação. Isso fica mais claro quando Austin afirma que "[...] evidentemente o performativo é derivado do verbo inglês to perform, verbo correlato do substantivo ação, e indica que ao se emitir o proferimento está se realizando uma ação, não sendo, consequentemente, considerado um mero equivalente a se dizer algo" (AUSTIN, 1990, p. 25).

Austin recorreu a um neologismo porque havia feito uma descoberta importante para a filosofia da linguagem: os enunciados linguísticos não servem somente para descrever um estado de coisas ou para afirmar algo sobre um fato, senão que com eles também realizam-se ações e que, portanto, existem também, além de enunciados constatativos, enunciados performativos. Austin, um atento leitor e pesquisador da obra de Wittgenstein, explicou a peculiaridade desta segunda forma de enunciados com a ajuda do que chamou "performativos explícitos". Quando alguém quebra uma garrafa contra o casco de um navio dizendo "batizo este navio com o nome de Rainha Elizabeth", ou quando em um casamento o funcionário do registro civil , após perguntar a ambos os cônjuges, pronuncia a frase "eu os declaro marido e mulher", não está sendo descrito um estado de coisas prévio. Por isso estes enunciados não podem ser considerados verdadeiros ou falsos. O que ocorre com eles é que, ao serem pronunciados, um novo estado de coisas foi criado: o navio passou a ser chamado de Rainha Elizabeth, e a senhora X e o senhor Y passaram a ser casados. O pronunciamento destes enunciados alterou circunstâncias anteriores. Os enunciados deste tipo não somente dizem algo, senão que realizam exatamente a ação que expressam. São autorreferenciais, porque significam o que fazem e são constitutivos da realidade, porque criam a realidade social que expressam. São estes dois traços distintivos que caracterizam os enunciados performativos. $\mathrm{O}$ que os falantes de todas as línguas sempre souberam e praticaram de forma intuitiva era formulado pela primeira vez pela filosofia da linguagem: a fala tem potência para modificar o mundo e para transformá-lo.

Os casos citados são exemplos de um modo de falar através de fórmulas, utilizando-se regras ou formas precisas e convencionalmente estabelecidas. Para garantir que um enunciado seja performativo, deve ser cumprida uma série de condições que não são somente linguísticas, de outro modo o enunciado corre o risco de cair numa espécie de discurso vazio. Se a frase "eu os declaro marido e mulher" não foi proferida nem por um funcionário do registro civil nem por um sacerdote ou outra pessoa expressamente autorizada para isso, então não haverá condições para se unir duas pessoas em matrimônio.

As condições a serem cumpridas para que um enunciado seja performativo não são, portanto, somente linguísticas, senão sobretudo institucionais e sociais. A enunciação performativa dirige-se sempre a uma comunidade em uma situação dada em que algum de seus membros deve estar presente representando-a. Neste sentido, implica a realização de um ato social. Com ela não somente se leva a cabo a união matrimonial, senão que, ao 
mesmo tempo, também se realiza uma espécie de ritual coletivo, ao qual passaremos a denominar como performance ou encenação ${ }^{15}$.

No desenvolvimento posterior de suas conferências, Austin abandonaria a contraposição entre enunciados constatativos e performativos, propondo em seu lugar, uma divisão constituída por três tipos de atos de fala: locutivos, ilocutivos e perlocutivos ${ }^{16}$. Com esta mudança, pode-se depreender que o principal objetivo de Austin era o de demonstrar que falar é sempre atuar, que consequentemente as constatações também podem ter êxito ou fracassar, e que os enunciados performativos também podem ser verdadeiros ou falsos. Portanto, o próprio Austin assume a inadequação de sua distinção entre enunciados performativos e constatativos. Isto pode ser entendido como um exemplo que demonstra a vulnerabilidade de todos os critérios definitivos e a exposição de todos os conceitos definitivos aos acasos, incertezas, imponderáveis e ambiguidades próprias da vida real. Assim, Austin desvia sua atenção para o fato de que justamente o performativo é o que coloca em marcha uma dinâmica que pode conduzir à desestabilização da ideia de esquema conceitual dicotômico.

Os pares conceituais dicotômicos do tipo sujeito / objeto ou significante / significado perdem sua polaridade e a nitidez de seus limites ao serem colocados em movimento e iniciarem a oscilação. Ainda que Austin, por vários motivos, tenha certificado o fracasso da dicotomia entre os conceitos de constatativo e performativo, isso não significa que ele questione a definição que ofereceu quando, num primeiro momento, referiu-se aos "performativos explícitos" como atos linguísticos autorreferenciais e constitutivos de realidade e como tais podem obter êxito ou fracassar, dependendo das condições sociais e institucionais. Como pode-se perceber em sua extensa e detalhada teoria sobre performativos felizes e performativos infelizes (devido a desacertos e maus usos), estes últimos eram para Austin os casos mais interessantes. Assim, uma das características do performativo que podemos apresentar é sua capacidade para desestabilizar e dissolver construções conceituais dicotômicas.

\section{Quinto movimento. Butler e os performativos nos atos do corpo.}

Sem remeter de forma expressa a Austin, Judith Butler ${ }^{17}$ introduz na filosofia da cultura o conceito de performativo em seu artigo de 1988 "Os atos performativos e a constituição do gênero: um ensaio sobre fenomenologia e teoria feminista". Neste trabalho ela pretendia demonstrar que a identidade de gênero não é prévia enquanto identidade, isto é, que não

\footnotetext{
${ }^{15}$ Encenação aqui no sentido de colocar em cena, aproximando-se dos conceitos de mise en scène e puesta en escena. Utilizo aqui duas breves definições para encenação, a de Jacques Copeau: "por encenação entendemos: o desenho de uma ação dramática. É o conjunto dos movimentos, dos gestos e das atitudes, o acordo das fisionomias, das vozes e dos silêncios, é a totalidade do espetáculo cênico" (FALEIRO, 2013:19), e a de André Veinstein, onde o termo encenação designa "a atividade que consiste no arranjo, num certo tempo e num certo espaço de atuação, dos diferentes elementos de interpretação cênica de uma obra dramática" (PAVIS, 2008:122).

16 Ao concluir que todos os enunciados são performativos (explícitos ou implícitos), Austin afirma que, ao ser pronunciado, todo enunciado realiza um ato de fala, pois realiza algum tipo de ação. Sua divisão em enunciados locucionários, ilocucionários e perlocucionários não é excludente, visto que, segundo ele, estes três atos acontecem simultaneamente. De forma resumida, podemos caracterizar o ato locucitório como o ato de dizer algo, utilizando expressões bem formadas em sua sintaxe (produção de sentido); o ato ilocucitório é a realização do ato enunciado (intenção do locutor no enunciado), sendo o ato perlocucionário a produção de efeitos e suas consequências para o receptor do enunciado.

17 Judith Butler (1956) é uma filósofa pós-estruturalista estadunidense, uma das principais teóricas da questão contemporânea do feminismo, teoria queer, filosofia política e ética.
} 
vem determinada ontológica ou biologicamente, senão que se entenda como o resultado de determinados esforços culturais de constituição: “[...] nesse sentido, o gênero não é de modo algum uma identidade estável nem lócus de agência do qual procederiam diferentes atos; ele é, pelo contrário, uma identidade constituída de forma tênue no tempo - uma identidade instituída por meio de uma repetição estilizada de atos" (BUTLER, 2018, p. 3). Butler chama estes atos de performativos: "consideremos o modo como o gênero, por exemplo, é um estilo corporal, um "ato", por assim dizer, ao mesmo tempo intencional e performativo, de tal forma que performativo possa significar tanto "dramático" quanto "não referencial" (BUTLER, 2018, p. 5). Ainda que, à primeira vista, esta definição do conceito pareça apresentar-se diferentemente em relação à de Austin, as diferenças se minimizam após um exame mais atento. É importante levar em conta sobretudo ao fato de que Butler não aplica aqui o conceito de performativo aos atos de fala, mas sim em relação a ações corporais.

Os atos performativos, enquanto atos do corpo, podem ser entendidos como não referenciais na medida em que não se referem a algo dado de antemão, a algo interno nem a uma substância ou um ser a que estes atos tenham que servir de expressão, pois não há identidade estável, fixa. A expressividade apresenta-se, neste sentido, como diametralmente oposta à performatividade. Os atos corpóreos aqui definidos como performativos não expressam uma identidade ontológica mas a sua rarefação ${ }^{18}$, e este processo parece ser seu sentido mais importante. Também o conceito de dramático aponta para este processo de rarefação:

Por dramática, quero dizer apenas que o corpo não é meramente matéria, mas uma materialização contínua e incessante de possibilidades. Não se é simplesmente um corpo, mas, em um sentido absolutamente fundamental, faz-se o próprio corpo e, é claro, cada um faz seu corpo de modo diferente de seus contemporâneos, e também de seus antecessores e sucessores corporificados (BUTLER, 2018, p. 5).

Isto significa que, também o corpo em sua particular materialidade, é o resultado de uma repetição de determinados gestos e movimentos. Unicamente este tipo de atos dão lugar ao corpo como algo individual, sexuado, étnico e culturalmente marcado. Assim, a identidade - como realidade corporal e social - constitui-se sempre através de atos performativos. Performativo significa neste sentido como em Austin constitutivo de realidade e autorreferencial.

O deslocamento de enfoque dos atos de fala para as ações físicas acarreta consequências que justificam o estabelecimento de uma distinção importante na definição de conceitos entre Austin e Butler. Se em Austin o critério mais importante eram as condições felizes ou infelizes para o modo de uso dos performativos e se perguntava, portanto, quais as condições necessárias para uma utilização feliz, Butler se pergunta pelas condições fenomenológicas da corporificação. Apelando a Merleau-Ponty ${ }^{19}$, que não

\footnotetext{
18 Utilizamos o conceito de rarefação como aparece em A ordem do discurso (FOUCAULT, 1996). Segundo Foucault, a rarefação seria um procedimento interno ao discurso, que funcionaria a título de princípios de classificação, de ordenação e de distribuição, uma possibilidade de multiplicação discursiva. "Por um lado permite construir (e indefinidamente) novos discursos: o fato de o texto primeiro pairar acima, sua permanência, seu estatuto de discurso sempre reatualizável (...) mas, por outro lado, (...) o de dizer enfim o que estava articulado silenciosamente no texto primeiro" (FOUCAULT, 1996, p. 25).

${ }^{19}$ Maurice Merleau-Ponty (1908-1961) foi um filósofo fenomenólogo francês.
} 
considera o corpo apenas como uma ideia histórica, mas também um conjunto de possibilidades continuamente realizáveis,

O corpo adquire significado por meio de uma expressão concreta e historicamente mediada no mundo. Dizer que o corpo é um conjunto de possibilidades significa que a) a sua aparição no mundo, do ponto de vista da percepção, não é determinada por nenhum tipo de essência interior; e b) a sua expressão concreta no mundo assume e torna específico um conjunto de possibilidades históricas (BUTLER, 2018, p. 4).

Butler explica o processo de geração performativa da identidade como um processo de corporificação (embodiment). Ela o define, portanto, como "um modo de fazer, dramatizar e reproduzir uma situação histórica” (BUTLER, 2018, p. 5). Mediante a estilizada repetição de atos performativos corporificam-se determinadas possibilidades histórico-culturais e somente assim se gera o corpo, histórica e culturalmente, e a identidade.

As condições nas quais se realizam em cada caso o processo de corporificação não se limitam exclusivamente ao âmbito do poder e das capacidades do indivíduo - não se pode escolher de forma totalmente livre quais possibilidades corporificam-se, nem quais identidades se quer adotar - nem tampouco estão completamente determinadas pela sociedade - ainda que a sociedade possa tentar impor a corporificação de determinadas possibilidades sancionando algumas discrepâncias que, de todo modo, não poderá evitar totalmente. Assim, no conceito de performativo proposto por Butler também se percebe claramente a potência, já apontada por Austin, de não se cair em dicotomias. Nos atos performativos e com os atos performativos, com os quais se constitui o gênero - e a identidade em geral -, a comunidade exerce violência corporal sobre o indivíduo. Mas ao mesmo tempo, em troca, estes atos oferecem a possibilidade de que neles, e com eles, cada indivíduo crie a si próprio - inclusive que seja à margem das ideias dominantes na comunidade e pagando o preço das correspondentes sanções sociais.

Butler compara as condições de corporificação com as das realizações cênicas (ou performances, ou encenações) teatrais, pois nelas os atos com os quais se criam e se realizam o pertencimento a um gênero não são de alguém isolado. "O ato que o gênero é, o ato que os agentes corporificados são - na medida em que corporificam dramática e ativamente determinadas significações culturais, além de propriamente vesti-las -, claramente não é um ato de alguém isolado" (BUTLER, 2018, p. 10). Trata-se de atos de uma "experiência partilhada", de uma "ação coletiva"; de fato, a ação realizada é uma ação em certo sentido iniciada sempre antes de que um determinado ator entre em cena. Assim, a repetição da ação é uma reconstituição da obra (reenactment) e uma reexperimentação (re-experiencing) de um repertório de significados socialmente estabelecidos de antemão. Nestes atos, não se inscrevem códigos culturais em um corpo passivo nem os eus corporificados precedem às convenções culturais que dão significado ao corpo. Butler compara a constituição da identidade através da corporificação com a encenação de um texto dramático pois que, de igual maneira, um mesmo texto pode ser levado à cena de formas distintas e que os atores, dentro das falas do mesmo, são livres para delinear e interpretar seu papel de um modo novo e diferente, um corpo que possua um gênero específico atua dentro dos limites das instruções da direção de cena. Assim, a realização da identidade de gênero, ou de qualquer outra, como processo de corporificação se leva a cabo de forma análoga ao de uma 
realização cênica teatral. Neste sentido, as condições para a corporificação podem ser descritas e definidas de modo mais exato como condições de realização cênica.

A teoria do performativo, tal como esboçado por Judith Butler no ensaio citado, ao colocar ênfase nos atos performativos corporais e conceder um grande peso aos processos de corporificação, parece estar cumprindo ao fim o que a teoria de Austin havia expressado como desejável em relação às condições de êxito. Ao explicar as condições de corporificação como condições para a realização cênica, Butler estabeleceu um interessante paralelismo entre sua teoria e a de Austin (ainda que ela não faça referência explícita a ele). Ambos consideram a realização dos atos performativos como uma realização cênica ritualizada e pública. Em ambos é possível estabelecer relações entre performatividade e realização cênica (performance, encenação). $\mathrm{Na}$ mesma medida em que as palavras 'performance' e 'performativo' são derivadas de 'to perform', parece que a performatividade conduz à realização cênica, manifesta-se e realiza-se no caráter de encenação dos atos performativos. No campo das artes, novas formas artísticas surgidas na segunda metade do século vinte, como a "arte da performance", já são um signo inequívoco de seu caráter performativo.

\section{Sexto movimento. Os performativos e suas relações nas encenações, performances e realizações cênicas contemporâneas.}

Desde os anos sessenta e setenta do século vinte tem surgido grande quantidade das mais variadas teorias da performance no campo das ciências sociais, particularmente na antropologia cultural e na sociologia, até chegar ao ponto de que, hoje em dia, possa ser considerado "[...] um conceito essencialmente contestado" (CARLSON, 2010, p. 5). Nos estudos culturais o conceito tem se convertido numa espécie de "guarda-chuva", o que vem gerando uma série de confusões conceituais.

Ao invés de recorrer a abordagens desenvolvidas nos campos da sociologia, da etnologia ou dos estudos culturais em geral, compartilhamos com Erika Fischer-Lichte ${ }^{20}$ (2011) que a investigação sobre o conceito de performativo deveria remontar às primeiras tentativas de teorização sobre performance, nas duas primeiras décadas do século vinte. Estas tentativas tinham como objetivo fundar uma nova disciplina acadêmica no campo das artes: os estudos teatrais.

Quando no princípio do século vinte foram fundados os estudos teatrais na Alemanha com sua posterior criação enquanto disciplina universitária autônoma e como uma nova e necessária área da teoria de arte, produziu-se uma ruptura com a ideia de teatro que havia predominado até aquele momento. Desde as intenções de literalização do século dezoito, o teatro impôs-se na Alemanha não somente como uma instituição moral, senão também como uma instituição “textual”. No final do século dezenove, o caráter artístico do teatro parecia legitimar-se quase que exclusivamente pela sua relação com a obra de arte

\footnotetext{
${ }^{20}$ Erika Fischer-Lichte (1943) é uma professora alemã de ciências teatrais na Universidade Livre de Berlim e diretora do Instituto de Estudos Avançados "Interrelações das Culturas Teatrais". É considerada uma das principais teóricas contemporâneas nas áreas dos estudos teatrais e artes performativas.
} 
dramática, ou seja, com o texto literário. Pode-se assinalar que, antes disso, Goethe ${ }^{21} \mathrm{em}$ texto de 1798, "Sobre a verdade e a probabilidade das obras de arte", havia formulado a ideia de que o caráter artístico do teatro residia na realização cênica. Foi Wagner ${ }^{22}$ quem retomou e desenvolveu esta ideia em seu escrito de 1849, “A obra de arte do futuro". Apesar disso, para a imensa maioria de seus contemporâneos do século dezenove, o valor artístico da encenação estava relacionado à representação do texto. Em 1918 o crítico teatral Alfred Klaar $^{23}$ escreveu no contexto de uma polêmica contra os então incipientes estudos teatrais: “[...] o cênico unicamente pode manter todo seu valor se a criação literária tiver mantido seu pleno significado" (FISCHER-LICHTE, 2011, p. 60).

Conforme este critério, o teatro considerava-se até então objeto dos estudos literários. Por outro lado, o fundador dos estudos teatrais em Berlim, Max Herrmann ${ }^{24}$, especialista em Idade Média e na primeira Modernidade, centrava sua atenção para a performance. Defendia a necessidade de se criar uma área dentro da teoria da arte - os estudos teatrais - com o argumento de que o que constitui o teatro como arte não é a literatura, senão a realização cênica. Herrmann não se conformava com uma mera troca de papéis que resultaria na preponderância da encenação sobre o texto, senão que defendia o estabelecimento de uma oposição essencial entre eles que terminaria excluindo sua vinculação, visto que o texto é a criação linguística-artística de uma só pessoa e o teatro é uma criação coletiva entre o público e aqueles que a realizam. Como nenhuma das disciplinas artísticas existentes incluía a performance entre seus objetos de estudo, somente se dedicavam aos textos, Herrmann teve que criar uma nova. Assim, os estudos teatrais na Alemanha foram fundados como a ciência da realização cênica.

A inversão dos termos texto e encenação que Herrmann propunha levar a cabo para defender a criação de uma nova disciplina que se ocuparia do teatro como performance e não como texto, teve uma interessante concomitância com a criação de outra disciplina na virada do século: a criação dos estudos sobre os rituais. Enquanto no século dezenove existia uma clara hierarquia entre mito e ritual, e se considerava que o mito tinha primazia e que o ritual era meramente uma recriação, ilustração ou representação dele, no final do século a relação entre estes conceitos experimentava uma inversão. Em suas "Palestras sobre a religião dos semitas" (1889), William Robertson Smith ${ }^{25}$ propôs a tese de que o mito servia meramente como interpretação de um ritual e, consequentemente, tinha um valor secundário. Em sua opinião a primazia deveria ser do ritual:

$\mathrm{Na}$ medida em que os mitos consistem em elucidações do ritual, seu valor é secundário, e pode-se assegurar que em quase todos os casos o mito surge do ritual e não o ritual do mito. O ritual era algo invariável e o mito, por outro lado, era variável;

\footnotetext{
${ }^{21}$ Johann Wolfgang von Goethe (1749-1832) foi um polímata, escritor e estadista alemão do Sacro Império RomanoGermânico que também fez incursões pelo campo da ciência natural. Considerado o maior escritor em língua alemã, tendo Fausto como aquela considerada sua obra-prima e um dos marcos do

22 Wilhelm Richard Wagner (1813-1883) foi um maestro, compositor, diretor de teatro e ensaísta alemão.

${ }^{23}$ Alfred Klaar (1848-1927) foi um crítico de teatro alemão, considerado um dos principais teóricos teatrais do início do século vinte na Alemanha.

${ }^{24}$ Max Herrmann (1865-1942) foi um historiador literário alemão e teórico dos estudos de teatro, considerado o pai fundador dos estudos teatrais na Alemanha.

25 William Robertson Smith (1846-1894) foi um orientalista escocês, estudioso do Antigo Testamento, professor de teologia e ministro da Igreja Livre da Escócia. Foi um dos editores da Enciclopédia Britânica. Também é conhecido pelo seu livro Religião dos semitas, que é considerado um texto fundamental no estudo comparativo da religião, institucionalizado pela Ciência da Religião.
} 
o ritual era obrigatório enquanto a crença no mito dependia da fé dos crentes (FISCHER-LICHTE, 2011, p. 62).

O interesse dos estudos religiosos deveria pois centrar-se no ritual. Assim, o princípio fundamental da religião seria a prática e não a doutrina, não o dogma. A preponderância dos textos religiosos, vigente até o momento sobretudo nas culturas protestantes, colocava-se seriamente em questão. Em suas investigações, Smith se ocupava especialmente dos rituais de sacrifício, como os de camelos, por exemplo, que eram frequentes entre as tribos árabes segundo as informações de um autor do século 4 d.C., de nome Nilo, ou nos rituais judeus de sacrifícios segundo o Antigo Testamento. Smith interpretava o sacrifício de camelos como uma ancestral prática totêmica e elaborou uma teoria segundo a qual havia que entender o animal sacrificado como centro de um banquete comunitário. A realização conjunta deste ato, a assimilação corporal e do sangue do animal sacrificado - de uma divindade, como a chama Smith adotando o sentido que atribui ao totemismo - uniria a todos os participantes por meio de um laço social indissolúvel. $O$ ritual antecede a instituição da comunidade pela primeira vez como comunidade de comensais, de tal maneira que o grupo que participa do ritual forma uma comunidade política. Pode-se depreender que estamos diante de atos performativos, que são aqueles que criam aquilo que realizam: a realidade social de uma comunidade (de comensais).

A teoria de Smith sobre o sacrifício teve uma grandíssima influência não somente nos estudos religiosos, mas também na etnologia, na sociologia e nos estudos sobre a Antiguidade. O etnólogo James George Frazer ${ }^{26}$ reconheceu sua dívida com Smith no prólogo da primeira edição de seu livro "O ramo dourado", de 1890, para o desenvolvimento da ideia principal defendida na obra, a concepção de um deus assassinado violentamente e ressuscitado. O sociólogo Émile Durkheim ${ }^{27}$ também se sentia em dívida com Robertson Smith, pois afirmou que somente após estudar suas palestras teve clara consciência da crucial importância da religião na vida social.

Os argumentos para fundar as investigações sobre o ritual e os estudos teatrais baseavam-se em premissas similares. Em ambos os casos tratava-se de uma inversão terminológica dentro de uma hierarquia: entre mito e ritual, em um caso, e entre texto literário e realização cênica, por outro. Em ambos os casos revogou-se a preponderância dos textos em favor da supremacia da encenação. Nessa medida pode-se afirmar que é já com a instauração das investigações sobre os rituais e dos estudos teatrais - e não com o surgimento da cultura da performance nos anos sessenta e setenta - quando se produz um primeiro giro performativo na cultura europeia do século vinte.

Jane Ellen Harrison ${ }^{28}$, líder dos chamados ritualistas de Cambridge, um grupo de filólogos especializados na Antiguidade, chegou ao extremo de estabelecer uma relação genealógica direta entre ritual e teatro que pretendia demonstrar a prioridade da realização cênica sobre o texto. Em seu extenso livro "Themis: um estudo da origem social da religião grega",

\footnotetext{
${ }^{26}$ James George Frazer (1854-1941) foi um influente antropólogo escocês nos primeiros estágios dos estudos modernos de mitologia e religião comparada.

27 David Émile Durkheim (1858-1917) foi um sociólogo, antropólogo, cientista político, psicólogo social e filósofo francês. Formalmente, tornou a sociologia uma ciência e, com Karl Marx e Max Weber, é comumente citado como o principal arquiteto da ciência social moderna e pai da sociologia.

${ }^{28}$ Jane Ellen Harrison (1850-1928) foi uma acadêmica, linguista e feminista britânica, fundadora (juntamente com Karl Kerenyi e Walter Burket) dos estudos modernos sobre mitologia grega.
} 
de 1912, desenvolveu uma teoria sobre a origem do teatro grego a partir do ritual. Harrison partiu da suposição da existência de um ritual pré-dionisíaco no qual se adorava a divindade da primavera. Entendia-se o ritual dionisíaco, por sua vez, como derivado deste antigo ritual. Harrison esforçou-se em apresentar provas para demonstrar que o ditirambo ${ }^{29}-$ do qual, segundo Aristóteles ${ }^{30}$, surgiu a tragédia - não estaria revivendo outra coisa que o canto da celebração da divindade da primavera, que é uma parte essencial deste ritual. Gilbert Murray ${ }^{31}$ contribuiu ao estudo de Harrison com seu "Excursão às formas rituais preservadas na tragédia grega". Remetendo-se a diversas tragédias, especialmente às "Bacantes", de Eurípedes ${ }^{32}$ - precisamente um dos textos trágicos mais tardios -, buscou demonstrar que elementos como a divindade, a elegia, o mensageiro e a epifania, os quais segundo Harrison integravam o ritual da divindade da primavera, cumpriam na tragédia funções similares às que cumpriam no ritual.

A teoria de Harrison deixava sem fundamento a convicção de seus contemporâneos de que a cultura grega, com respeito a cujo modelo e a cujos parâmetros modelaram a sua, havia sido uma cultura textual. À luz de sua teoria, os tão admirados textos das tragédias e das comédias gregas seriam a última consequência das ações pelas quais se realizava um ritual em homenagem ao deus de uma estação. Primeiro seria o ritual, e a partir dele teriam se desenvolvido o teatro e os textos escritos para serem realizados por ele.

A teoria de Harrison contribuiu decisivamente para sustentar a ideia de um giro performativo. O que faltava ao conceito de encenação para converter-se em um conceitochave era uma minuciosa fixação teórica. Herrmann se propôs a realizar esta tarefa por meio de diversos trabalhos entre 1910 e 1930.

É significativo que Herrmann situe como ponto de partida e pedra angular de suas reflexões a relação entre atores e espectadores:

O sentido originário do teatro radica em que era um jogo social - um jogo de todos para todos. Um jogo no qual todos participavam - protagonistas e espectadores. O público tomava parte no conjunto de maneira ativa. O público é, por assim dizer, criador da arte do teatro. Há tantas partes distintas implicadas na configuração da festa teatral, que é impossível que se perca seu essencial caráter social. No teatro sempre acontece, se realiza, uma comunidade social (FISCHER-LICHTE, 2011, p. 65).

Somente porque se dá a copresença física de atores e espectadores pode ter lugar a performance, é esta copresença o que a constitui. Para que uma realização cênica possa ter

\footnotetext{
${ }^{29}$ Nas origens do teatro grego, o ditirambo era um canto coral de caráter apaixonado (alegre ou sombrio), constituído de uma parte narrativa, recitada pelo cantor principal, ou corifeu, e de outra propriamente coral, executada por personagens vestidos de faunos e sátiros, considerados companheiros do deus Dionísio, em honra do qual se prestava essa homenagem ritualística.

30 Aristóteles (384 a.C. - 322 a.C.) foi um filósofo grego durante o período clássico na Grécia Antiga, fundador da escola peripatética e do Liceu, além de ter sido aluno de Platão e professor de Alexandre, o Grande. Seus escritos abrangem diversos assuntos como: a física, a metafísica, as leis da poesia e do drama, a música, a lógica, a retórica, o governo, a ética, a biologia, a linguística, a economia e a zoologia. É considerado juntamente com Sócrates e Platão um dos fundadores da filosofia ocidental. Sua obra Arte Poética é considerada o primeiro tratado sobre teatro da história e exerce profunda influência até os dias de hoje, especialmente os conceitos de objeto estético e mimese.

${ }^{31}$ George Gilbert Aimé Murray (1866-1957) foi um erudito e intelectual britânico nascido na Austrália, estudioso da língua e da cultura da Grécia Antiga.

32 Eurípedes (480 a.C. - 406 a.C.) foi um poeta trágico grego, o mais jovem dos três grandes expoentes da tragédia grega clássica, que ressaltou em suas obras as agitações da alma humana e em especial a feminina.
} 
lugar, atores e espectadores têm de reunir-se durante um determinado período em um lugar concreto e fazer algo juntos. Ao definir o sentido originário do teatro como "um jogo de todos para todos", Herrmann definiu a relação entre atores e espectadores de um modo essencialmente novo. Os espectadores já não são considerados observadores distantes ou próximos das ações realizadas pelos atores no palco e que eles, a partir de suas observações, atribuem-lhes determinados significados, nem como intelectuais decifradores das mensagens formuladas com as ações dos atores e a partir delas. Não estamos ante uma relação entre sujeito e objeto, nem no sentido de que os espectadores convertam os atores em objeto de suas observações, tampouco em que os atores como sujeitos e os espectadores como objetos enfrentem-se com mensagens inegociáveis. Por copresença física se entende melhor como a relação de cossujeitos. Os espectadores são considerados parte ativa na criação da encenação por sua participação no jogo, pela sua presença física, por sua percepção e pelas suas reações. A performance surge então como resultado da interação entre atores e espectadores. As regras que a fazem possível são entendidas como regras de um jogo que são estabelecidas entre todos os participantes - atores e espectadores - e que podem ser igualmente respeitadas ou não por ambas as partes. A realização cênica acontece entre atores e espectadores, é criada por ambos conjuntamente.

Provavelmente Herrmann não chegou a esta definição da singular mediação do teatro baseando-se unicamente em reflexões puramente teóricas ou derivadas da história do teatro. As encenações teatrais de sua época contribuíram para isto. Foi sobretudo Max Reinhardt ${ }^{33}$ quem, em suas montagens, trabalhava uma e outra vez disposições espaciais novas que obrigavam os espectadores a abandonar a posição de observadores própria das salas de teatro clássicas, os chamados teatros à italiana, e lhes possibilitava novas formas de interação com os atores. Em “Sumurun” (1910), por exemplo, Reinhardt estendeu um hanamichi (uma ampla passarela utilizada tradicionalmente no teatro kabuki japonês) que atravessava a plateia do teatro. Deste modo os acontecimentos sucediam-se em meio aos espectadores. Reinhardt fazia com que cenas acontecessem no palco e no hanamichi simultaneamente, de tal maneira que os atores apareciam sobre a passarela justamente em um momento crucial em cada uma das cenas. Era inevitável que os espectadores que olhavam para os atores que apareciam no hanamichi perdessem irremediavelmente o que estava acontecendo no palco. Aqueles que, pelo contrário, preferiam seguir o que ocorria no palco, perdiam as intervenções dos atores na passarela. Deste modo, obrigando-os a selecionar autonomamente as impressões sensíveis, os espectadores convertiam-se em sentido enfático em "criadores" da performance. O jogo da realização cênica era levado a cabo segundo as regras estabelecidas de uma parte pelos atores (e pelo diretor) e de outra pelos espectadores. Eram negociáveis.

A primeira vez que isto se pôde aplicar de modo estrito foi nas montagens de Édipo Rei, de Sófocles ${ }^{34}$ (1910) e da Oresteia, de Ésquilo ${ }^{35}$ (1911), que o próprio Reinhardt realizou em Berlim. Neles, o coro movia-se continuamente entre o público, os atores apareciam

\footnotetext{
33 Max Reinhardt (1873-1943) foi um produtor e diretor de teatro austríaco, tendo alcançado notoriedade por suas grandes produções e, contemporaneamente, objeto de estudo pelas experiências que realizou com diversas formas e estilos teatrais. De família judia, desenvolveu sua carreira na Alemanha, tendo que emigrar para os Estados Unidos devido ao nazismo.

34 Sófocles (497 a.C. - 406 a.C.) foi um dramaturgo grego, um dos mais importantes escritores de tragédia ao lado de Ésquilo e Eurípedes.

35 Ésquilo (525 a.C. - 456 a.C.) foi um dramaturgo grego, considerado o pai da tragédia.
} 
por trás, pela frente e no meio dos espectadores. Alfred Klaar, que posteriormente recrudesceria a polêmica com Max Herrmann sobre a preeminência do texto sobre a realização cênica, queixava-se a respeito da Oresteia que:

\begin{abstract}
A distribuição da ação, em frente, no meio, abaixo e atrás de nós; essa incessante necessidade de mudar o ponto de vista; essa invasão da plateia por parte dos atores, que com seus trajes ondulantes, perucas e maquiados aproximavam-se de nós; esses diálogos mantidos à distância; esses gritos repentinos desde qualquer parte do teatro que nos sobressaltava e desorientava; tudo isso disperso: não alimentava a ilusão, a extinguia (FISCHER-LICHTE, 2011, p. 67).
\end{abstract}

Aos espectadores, nesta situação, era impossível colocar-se no lugar de meros observadores, não lhes restava outro remédio que reorientar-se continuamente tanto com respeito aos atores quanto com respeito aos demais espectadores. A encenação acontecia neste caso literalmente entre atores e espectadores, assim como entre os próprios espectadores. Reinhardt supôs aproveitar das mais diversas maneiras a singulares condições de mediação através da copresença física de atores e espectadores com a intenção de fazer possíveis novas relações entre eles, de criá-las continuamente.

De acordo com sua ideia de que toda performance acontece entre atores e espectadores, isto é, que não é nem fixável nem transmissível, senão fugaz e transitória, no momento de formular sua definição de realização cênica Herrmann não se ocupou nem dos textos encenados nem dos artefatos que são utilizados, por exemplo, através dos cenários. Mostrou sua oposição, efetivamente, às pinturas de fundo da cena, tanto se fossem de estilo naturalista como se fossem expressionistas - apesar que reconhecia, em muitos casos, seu valor artístico - e as tachou de erros de princípio de consequências decisivas. A seu juízo tratava-se de elementos irrelevantes para o conceito de encenação. A singular e efêmera materialidade da performance constituía-se melhor através dos corpos dos atores que se movem no / pelo espaço. "Na arte da atuação radica o essencial do sucesso teatral, e somente ela cria a obra de arte autêntica e mais pura que o teatro é capaz de produzir" (HERRMANN apud FISCHER-LICHTE, 2011, p. 68). Neste contexto, parece não interessar muito a Herrmann o personagem e o mundo fictício criados para a arte interpretativa. Fala, isso sim, de "corpo real" e de "espaço real", não concebendo o corpo do ator no espaço cênico como mero portador de significado, como era habitual desde o século dezoito, senão que se centra na materialidade específica do corpo e do espaço. São eles os que contribuem em maior medida para a constituição da realização cênica, e não meramente os personagens e os espaços fictícios criados nela.

No tocante a este aspecto encontra-se igualmente um chamativo paralelismo no teatro de Max Reinhardt. Os novos espaços teatrais que criou, por exemplo, com o banamichi ou com a ocupação da plateia na Oresteia, não estavam a serviço de uma nova recriação de lugares fictícios em consonância com o texto literário. Como "lugares reais" possibilitavam aos atores novas possibilidades de aparecerem em cena, de moverem-se por ela ou, em um sentido mais amplo, novas opções de interpretação, enquanto aos espectadores abriam-se novas possibilidades de percepção e de experimentação.

Há muitos argumentos que podem sustentar uma afirmação de que Herrmann, assim como Judith Butler, considerava a expressividade e a performatividade como conceitos mutuamente excludentes. Assim, parece confirmar-se o conceito de performance 
que desenvolveu. Ao converter o aspecto essencial de sua definição tanto a copresença física de atores e espectadores, que conjuntamente fazem que a realização cênica aconteça, como as ações corporais realizadas por ambos os grupos, e ao centrar com ele sua atenção em um processo dinâmico, imprevisível tanto em seu transcurso como em seu resultado, afasta a expressão e transmissão de significados previamente dados. Os significados que surgem neste processo somente podem ser produzidos nele e por ele. Herrmann não chegou a esta conclusão, ao menos não explicitamente. Por esse motivo, em sua definição do conceito de encenação as reflexões sobre sua semioticidade específica, sobre sua singular maneira de gerar significados carecem de relevância (FISCHER-LICHTE, 2011).

Ao entender performance como uma festa e como um jogo - como aquilo que acontece entre atores e espectadores -, ao descrever sua materialidade específica como efêmera, como um processo dinâmico e não como um artefato, um produto, Herrmann priva de fundamento o emprego da expressão "obra-de-arte"36 no caso da realização cênica - ainda que, ao defender a condição do teatro como arte autônoma, fale da interpretação dos atores como a autêntica, a mais pura obra de arte que o teatro é capaz de produzir. Há que se ter em conta que o critério dominante em seu tempo era o de que a arte estava necessariamente ligada ao conceito de obra. Visto desde a perspectiva atual a definição de encenação de Herrmann exclui o conceito de obra. A performance não adquire seu caráter artístico - sua esteticidade - pela obra que supostamente criou, senão pelo acontecimento que como tal realização cênica executou. A realização cênica tal e como a entende Herrmann dá lugar a uma constelação única, irrepetível, sobre a que a maioria das vezes somente se pode exercer uma influência e um controle limitados, e na qual ocorre algo que somente pode acontecer desta maneira uma vez - como não poderia ser de outro modo tratando-se do encontro de um grupo de atores com um certo grupo de espectadores de temperamentos, estados de ânimo, desejos, ideias e conhecimentos distintos, em um determinado momento e num determinado lugar. Nesta situação, a Herrmann interessavalhe, acima de tudo, as atividades e os processos dinâmicos nos quais os dois grupos implicavam-se.

Assim, Herrmann considera a atividade criativa que estende ao espectador como “[...] um furtivo ressuscitar, uma enigmática réplica do trabalho dos atores que é assimilado não tanto pelo sentido do que se vê quanto pelo sentido que mobiliza todo o corpo, um secreto ímpeto interno que o leva a executar os mesmos movimentos, a reproduzir o mesmo tom de voz em sua garganta" (FISCHER-LICHTE, 2011, p. 73).

Com isto se insiste em que para a experiência estética o mais decisivo teatralmente na encenação é a experiência conjunta dos corpos reais em um espaço real. Não se entende a atividade do espectador como um mero exercício de sua fantasia, de sua imaginação que é a impressão que se pode ter em uma leitura apressada -, senão como um processo físico. Este processo coloca-se em marcha ao tomar parte em uma performance por meio de uma percepção que não é realizada somente através dos olhos ou dos ouvidos, senão também pelo sentido corporal, realizada pelo corpo inteiro de maneira sinestésica.

Os espectadores reagem não somente às ações físicas dos atores, mas também em relação ao comportamento dos outros espectadores. Sempre haverá indivíduos na plateia

\footnotetext{
36 "Obra-de-arte" é entendida aqui como um produto que transmite uma ideia ou uma expressão sensível, criada ou avaliada por sua função artística.
} 
com maior resistência ao jogo cênico, assim poderemos ter casos em que estas pessoas possam vir a contagiar os demais (com predisposição para deixarem-se envolver com a experiência teatral), afastando-os da possibilidade de tomarem parte mais ativa na performance, ou o contrário, elas serem contagiadas animicamente pelos demais. A metáfora do contágio volta a deixar claro que quando falamos de experiência estética no contexto de uma realização cênica não estamos nos referindo a uma obra, senão ao que surge a partir daquilo que acontece entre os que tomam parte nela. Por isso, neste caso, é mais importante a emergência do que ocorre do que exatamente o que ocorre, e ainda mais importante que os significados que se possam atribuir.

No fundo, o conceito de encenação de Herrmann implica uma substituição do conceito de obra pela de acontecimento, sendo que a específica esteticidade da performance funda-se na sua condição (FISCHER-LICHTE, 2011).

O conceito de realização cênica de Herrmann, tal e como foi reconstruído a partir de diversos escritos e intervenções orais do autor - recolhidos em apontamentos de seus alunos -, resulta em uma ampliação do conceito de performativo segundo posteriormente definido por Austin e por Butler. A definição de Herrmann concorda com as mais modernas na medida em que não entende a realização cênica como representação ou expressão de algo prévio ou dado, senão como o resultado de uma criação genuína: tanto a encenação mesma como sua materialidade específica se produzem unicamente no processo de execução pelas ações de todos que tomam parte nela. O conceito de performance de Herrmann vai mais longe que o conceito de performativo de Austin e Butler na medida em que insiste na troca que durante a realização cênica se leva ao cabo nas relações entre sujeito e objeto, por um lado, e entre materialidade e semiose, por outro.

\section{Sétimo movimento. Acontecimento.}

Ideia central na conceituação de realização cênica de Max Herrmann, o conceito de acontecimento recebe tratamentos diversos em relação à sua utilização filosófica. No curto verbete proposto por Abbagnano, trata-se de "[...] um fato ou um evento que tem certo caráter acidental ou fortuito ou, pelo menos, do qual não se pode excluir esse caráter" (ABBAGNANO, 2012, p. 15). Para os estoicos, acontecimento estava relacionado aos corpos, especialmente aos efeitos gerados pelo encontro dos corpos no mundo. Regina Schöpke considera que, ao reativar o conceito de acontecimento, Gilles Deleuze aponta para duas direções:

De um lado, ele aponta para a realidade, tem uma ontologia; de outro, ele aponta para a linguagem, porque o ser é também aquilo que se diz, ou seja, o ser é dito é pela linguagem. Assim, todo acontecimento teria duas faces: a real, o mundo, e a linguagem, o sentido. É aqui que entra a lógica dos incorporais, porque num sentido bem claro só existe o corpo, que está sempre no presente, sendo a mudança o que está na esfera do devir. (SCHÖPKE, 2010, p. 15).

Por um lado, há corpos com suas qualidades físicas, relações, ações e paixões. Trata-se de estados de coisas vividos determinados pelos encontros dos corpos. Por outra parte, todos os corpos são, por sua vez, causa de certas coisas de uma natureza completamente diferente. Os efeitos não são coisas ou corpos senão incorporais ou 
acontecimentos. Não existem senão subsistem ou insistem; não pertencem ao mundo como coisas senão como entidades inexistentes. São resultados de ações e de paixões. Nos corpos há encontros que determinam estados de coisas quantitativos e qualitativos, mas também há acontecimentos incorporais de superfície que são resultado destes encontros. Os acontecimentos são efeitos de superfície que se atribuem aos encontros de corpos que lhes causaram. De fato, esta distinção impede que o acontecimento seja confundido com um fato regular e ordinário, com o acidente. Poder distinguir os incorporais dos acidentes e a potência de sua efetuação espaçotemporal é manter na filosofia um puro acontecimento como verdade eterna, muito além de sua efetuação histórica. Para Deleuze ambas dimensões fazem o conceito de acontecimento e não se deveria omitir nenhuma delas porque o acontecimento puro é reserva de potência e intensidade e sua efetuação produz os signos de sua trajetória e as pegadas de seu efeito na extensão. Segundo Deleuze,

\begin{abstract}
Os acontecimentos são ideais. Novalis chega a dizer que há duas ordens de acontecimentos: uns ideais, os outros reais e imperfeitos, por exemplo o protestantismo ideal e o luteranismo real. Mas a distinção não é entre duas espécies de acontecimentos, mas entre o acontecimento, por natureza ideal e sua efetuação espaçotemporal em um estado de coisas. Entre o acontecimento e o acidente. Os acontecimentos são singularidades ideais que comunicam em um só e mesmo Acontecimento; assim possuem uma verdade eterna e seu tempo não é nunca o presente que os efetua e os faz existir, mas o Aion ilimitado, o Infinitivo em que eles subsistem e insistem. Os acontecimentos são as únicas idealidades; e reverter o platonismo é, em primeiro lugar, destituir as essências para substituí-las pelos acontecimentos como jatos de singularidades. Uma dupla luta tem por objeto impedir toda confusão dogmática do acontecimento com a essência, mas também toda confusão empirista do acontecimento com o acidente (DELEUZE, 2011, p. 56).
\end{abstract}

Em sentido amplo, a noção inclui o acontecimento corpóreo e sua efetuação em um estado de coisas vivido; em sentido restrito, limita-se ao acontecimento puro, deixando de lado os acidentes ou estados de coisas que o efetuam. Os acontecimentos são expressos por proposições que não se confundem com elas. "Não perguntaremos, pois, qual é o sentido de um acontecimento: o acontecimento é o próprio sentido. O acontecimento pertence essencialmente à linguagem; mas a linguagem é o que se diz das coisas" (DELEUZE, 2011, p. 23).

\title{
Oitavo movimento. Pistas.
}

Os atos performativos, sejam os de fala (Austin/Wittgenstein), os do corpo (Butler) ou os da performance (Herrmann/Fischer-Lichte) podem ser percebidos pelo atravessamento de algumas características, como serem operativos (com eles estão sendo realizadas ações); autorreferenciais (porque significam o que fazem e não se referem a algo dado de antemão, algo interno nem a uma substância ou ser a que estes atos tenham de servir de expressão); constitutivos da realidade (criam a realidade social que expressam); implicam a realização de um ato social (um ritual coletivo, uma experiência partilhada); desestabilizam e dissolvem construções conceituais dicotômicas (como sujeito / objeto ou significante / significado); são intencionais e dramáticos (através da repetição de determinados gestos e movimentos estilizados); 
criam materializações contínuas e incessantes de possibilidades, são físicos e não estão relacionados à ideia de "obra", mas sim de "acontecimento".

A arte contemporânea, atravessada pelos elementos do ritual, da festa, do jogo e de suas regras, incorpora o acaso e suas manifestações justamente por se tratar de um processo dinâmico, um acontecimento que integra todos os seus envolvidos como criadores e jogadores, de efeitos imprevisíveis tanto durante seu transcurso como em seu resultado, afastando imanentemente a expressão e transmissão de significados previamente dados.

Os atos performativos, portanto, potencializam o desnudamento da vulnerabilidade de todos os critérios definitivos, colocando-os à sujeição do acaso, das incertezas, dos imponderáveis e ambiguidades próprias do acontecimento.

\section{Referências}

ABBAGNANO, Nicola. Dicionário de filosofia. Trad. de Alfredo Bosi e Ivone Castilho Benedetti. São Paulo: Editora WMF Martins Fontes, 2012.

AUSTIN, John Langshaw. Quando dizer é fazer - palavras e ação. Trad. de Danilo Marcondes de Souza Filho. Porto Alegre: Artes Médicas, 1990.

BUTLER, Judith. Os atos performativos e a constituição do gênero: um ensaio sobre fenomenologia e teoria feminista. Trad. de Jamille Pinheiro Dias. Belo Horizonte: Edições Chão da Feira, 2018.

CARLSON, Marvin. Performance:uma introdução crítica. Trad. de Thaís Flores Nogueira Diniz e Maria Antonieta Pereira. Belo Horizonte: UFMG, 2010.

DELEUZE, Gilles. Lógica do sentido. Trad. de Luiz Roberto Salinas Fortes. São Paulo: Perspectiva, 2011.

FALEIRO, José Ronaldo. Sobre a encenação e o encenador no teatro. Móin-Móin Revista de Estudos sobre Teatro de Formas Animadas, Florianópolis, v. 1. n. 10. Florianópolis, p. 14-29, Julho, 2013.

FISCHER-LICHTE, Erika. Estética de lo performativo. Trad. de David Martínez Perucha y Diana González Martín. Madrid: Abada Editores, 2011.

FOUCAULT, Michel. A ordem do discurso. Trad. de Laura Fraga de Almeida Sampaio. São Paulo: Loyola, 1996.

GLUSBERG, Jorge. A arte da performance. Trad. de Renato Cohen. São Paulo: Perspectiva, 2013. 
MIGUEL, Antonio. Historiografia e terapia na cidade da linguagem de Wittgenstein.

Bolema - Boletim de Educação Matemática, Rio Claro (SP), v. 30, n. 55, p. 368-389, Agosto, 2016.

PAVIS, Patrice. Dicionário de teatro. Trad. de J. Guinsburg e Maria Lúcia Pereira. São Paulo: Perspectiva, 2008.

SCHÖPKE, Regina. Dicionário filosófico: conceitos fundamentais. São Paulo: Martins Fontes, 2010.

WITTGENSTEIN, Ludwig. Investigações filosóficas. Trad. de Marcos G. Montagnoli e Emmanuel Carneiro Leão. Petrópolis, RJ: Vozes, 2014.

Investigações filosóficas. Trad. de José Carlos Bruni. São Paulo: Editora Nova Cultural, 2000. 